\title{
Thoughts on China's Growth of Economy and Inflation
}

\author{
Jingmin Wang \\ Economics and Management School, Wuhan University, Wuhan 430072, China \\ Isotope Institute, Henan Sciences Academy, Zhengzhou 450015, China \\ Tel: 86-371-68985064 E-mail: hnwjm@yahoo.com.cn \\ Jianqing Zhang \\ Economics and Management School, Wuhan University, Wuhan 430072, China \\ Tel: 86-27-68753170 E-mail: jqzhang@whu.edu.cn
}

\begin{abstract}
In China, the constantly increasing CPI (Consumer Price Index) has become a prominent signal that indicates an overheated macro economy. An overheated economy and future surplus productivity will lead to a prediction of inflation, which will sustain the inflation in an evil circulation driven by costs and pulled by demand. As a result, it will cause severe financial instability. Therefore, applying a tight monetary policy, adopting a package of control measures, optimizing the structure of economy, and improving the quality of economic growth can help to achieve a fast and healthy development of national economy.
\end{abstract}

Keywords: China, Economy, Growth, Inflation, Thoughts

The economic blue book, Analyze and Predict China's Economy in 2008, composed by China Academy of Social Sciences, points out that the constantly increasing CPI (Consumer Price Index) has become a prominent signal that indicates an overheated macro economy. Affected by the increasing prices of pork and edible oil, China CPI break through the warning line 3\% in March and kept on increasing. And in August and October it reached the new highest $6.5 \%$ in ten years (China Academy of Social Sciences, 2007).

This year, national economy stays on a high position and growth of economy is fast. The troika of the growth of economy, especially the investment and the export, kept on a fast increase. Prices of consumables and assets achieved a significant rise. More pressures come from resources and environment. All these facts indicate an overheated economy in China. Some people may connect present price rises with the fast growth of China economy, because it is common that the fast growth of economy is accompanied with inflation. For example, the rise of Japan's economy after the World War II and the growth of Korea's economy are all accompanied with inflation in a sense, especially the price rises of foods. Before the economy bubble cracked in Japan, the price of food had rise to an unbelievable degree. At that time, the prominent feature of Japan economy is the severe distortion of prices. All goods in domestic market were rising crazily. But goods for exports were staying relatively lower prices.

At present, the situations in China are similar to Japan in $80 \mathrm{~s}$ and $90 \mathrm{~s}$ in a sense. The foreign exchange rises fast. Liquidity surplus is severe. Domestic currency faces more appreciating pressure. Since the exchange reform in July, 2005, the accumulated appreciation of RMB exchange rate to American dollar has been close to 8\%. It means China's exported goods become more expensive in the world market. But on the other hand, the purchasing power of RMB is decreasing in domestic market. In other words, RMB is depreciating in China's domestic market.

The outside appreciation of RMB will lead to the decrease of export, which can counteract the increasing trade surplus and help to solve trade conflicts to certain degree. However, the outside appreciation of RMB also means a shrink of China's exchange reserve. Theoretically, RMB appreciation can make imported goods become cheaper in domestic market. Chinese can exchange RMB for more American dollars and invest them in foreign countries. But under present situations, the benefits generated from the RMB outside appreciation are limited.

The inside depreciation of RMB means a decrease of people's disposal income. In other words, it means fewer goods that can be bought by same income. The real income becomes less. Therefore, although we can not predict the effects generated by the outside appreciation of RMB, the inside depreciation and the outside appreciation of RMB at the same time deserve more attentions indeed.

Comparing with the fast increasing potential and real output, the increase of domestic demand is still insufficient instead of being overheated. In 2006, the contribution rate of net exports to China's economy growth is from 3\% to $4 \%$. Besides, China's domestic demand may fail to support the growth rate of economy $9 \%$. In 2007, China's net exports 
will exceed 300 billion American dollars. If China can not sustain the exports, China's economy growth may decrease significantly due to the output surplus. In other words, although China's economy is overheated at present, the overheated economy will turn into deflation. Because the high investment ratio and the high fixed assets' investment ratio are features of China's economy growth, present overheated economy caused by excessive investment will lead to deflation in future that is originated from surplus productivity (Rudiger Dornbusch., Stanley Fischer \& Richard Startz, 2007).

At present, China faces an overheated economy at present and surplus productivity in future. Anyway, present inflation has already threatened the stability of economy. Firstly, it causes the prediction for inflation, which will sustain the inflation in an evil circulation driven by costs and pulled by demand. Secondly, inflation and asset bubbles will exert effects on each other, which may lead to severe financial instability. Presently, the most dangerous feature of China's economy is the intergrowth of inflation and asset bubbles.

According to information issued by The Central Economic Work Conference closed on 5th, December, 2007, the moderate monetary policy that has already applied for ten years will be turned into the tight monetary policy. The conference establishes the general goal of economic work in next year. Follow the spirit of 17th CPC National Congress and hold the flag of China's socialism. Take Xiaoping Deng's theories and the "three representatives" as the guidance. Apply the idea of scientific development. Change the development mode of economy. Perfect the socialist market system. Enhance and improve the macro control. Support the reform and open policy, and self-innovation. Lay stresses on optimizing economic structure and improving the quality of economic growth. Emphasize on saving energy and reducing emission and ecological environment protection. Focus on improving people's livelihood and try to achieve a social harmonious. Push the national economy toward fast and healthy development (Xinhua News, 2007).

The tight monetary policy proposed by the central government is different from the moderate tight policy, which is not common in recent years in China. Deleting the word "moderate" indicates the strengths of policy. In general, along with the deepening macro control, China's structural adjustment shows kind of positive changes. The troika, namely the investment, the export, and the consumption, contributes to the growth of economy together. However, although the contribution ratio of consumption to the growth of economy increases to certain degree, the proportion of consumption to investment is still unbalance. During the first three seasons, the contribution ratio of consumption to economic growth is $37 \%$, but that of investment $41.6 \%$ (WWW.CE.CN, 2007). In order to solve the demand structure conflict in present economic growth, it is a must to adopt a package of adjustment and control measures. There into, the principal measure is to apply a protective and suppressive industrial policy, controlling the irrational investment demand and export demand. At the same time, it is necessary to reform the income allocation system and perfect the social security system. Besides, pay attention to avoid the inflation and its effect on low-income people's basic consumption ability.

\section{References}

China Academy of Social Sciences. (2007). Analyze and Predict China's Economy in 2008. Beijing: Social Sciences Academic Press (China). Dec.

Rudiger Dornbusch., Stanley Fischer \& Richard Startz. (2007). Macroeconomics (Edition 7th). Beijing: China Renmen University Press. Apr.

Xinhua News. (2007). A tight monetary policy will be applied next year. Dahe Daily. A02, 6th, Dec.

WWW.CE.CN. (2007). http://www.ce.cn/cysc/zjxw/200712/06/t20071206_13825069.shtml. 6th, Dec. 